\title{
Journalistik som socialt felt
}

\author{
Af Iben Jensen
}

Den daglige omgang med medier skaber sarlige forestillinger om etnisk ligestilling $i$ det danske samfund. Sporgsmålet er, hvilke verdier om etnisk ligestilling der kommer til udtryk gennem pressen. Med Bourdieus feltbegreb undersøger Iben Jensen i denne artikel journalistik som socialt felt. Gennem en undersøgelse af journalistuddannelsernes adgangskrav, udvalgte medieinstitutioner samt journalisternes fagforening blotlagges feltet ud fra forskellige lesninger. Artiklen afsluttes med en redegorelse for de forskellige logikker, der hersker $i$ det sociale felt journalistik.

»Indvandrere fylder specialklasserne - Indvandrerbørn får specialundervisning i langt højere grad end danske børn, især på grund af indavk«. Overskriften henviser til en ny undersøgelse, som viser, at indvandrerbørn er overrepræsenteret i specialklasserne. I artiklen citeres amtspsykolog Ove Carlsen samtidigt for at sige: »...- og vi mangler grundige undersøgelser på området. Men vores antagelse er, at overrepræsentationen hovedsageligt skyldes fætter- og kusineægteskaber, hvor genetiske problemer nedarves på grund af indgiftning" (Forsiden på Information d. 6. maj 2000, min understregning). Det er ikke enestående, at en journalist bruger »danske børn« og »indvandrerbørn«, som om betegnelserne udelukker hinanden (børn i Danmark er danske, men kan have forskellig etnisk baggrund). Det er heller ikke enestående, at journalisten formulerer en påstand på baggrund af en antagelse som f.eks. »især på grund af indavl (artiklen blev efter sigende dementeret dagen efter - på side 11). Ej heller er det enestående, at journalisten ikke har bedrevet kritisk journalistik og opsøgt mere end én kilde til sin artikel (de to citerede eksperter er foredragsholdere ved samme konference). Det interessante spørgsmål er her: Hvorfor er det almindeligt? Hvordan kan denne historie være en forsidehistorie i Information? Hensigten med min artikel er, med hjælp fra Pierre Bourdieu, at undersøge, hvilke mønstre der dukker op omkring etnisk ligestilling, når man ser journalistik som et socialt felt. Hvad er det for logikker og værdier, der dominerer inden for det so- ciale felt, man kan kalde journalistik? Samtidig er det min hensigt at afprøve nogle af Bourdieus centrale begreber på et konkret empirisk materiale. ${ }^{1}$

\section{Historiens forklaringer}

Medieforskningen har gennem tiden forsøgt sig med forskellige forklaringer på journalister og filmmageres værker. I 70'ernes marxistiske mediekritik talte man meget om mediernes fremmedgørende indflydelse på masserne. Forordet til antologien »Filmanalyser« (udgivet på Røde Hane i 1974) er et godt eksempel på den tids argumentation. Redaktionen ønskede at sætte filmanalyserne i et historisk samfundsmæssigt perspektiv:

... fordi den synsmåde, som er anlagt i disse analyser, kan bidrage til at gøre biografgængeriet til et led i en proces, der gør ens egne og ens omgivelsers forestillinger om de samfundsmæssige sammenhænge mere begribelige. Derved muliggøres en erkendelse af de virkelige forhold, der undslipper de mystifikationer, forskydninger og tilsløringer, som er et karakteristisk træk ved film - såvel som andre kulturelle produkter. Ikke mindst medlemmerne af de såkaldte mellemlag, dvs. de som hverken tilhører det egentlige borgerskab eller arbejderklassen, har meget vanskeligt ved at trænge igennem de nærliggende forestillinger og frem til realitetserkendelse (Andersen m.fl. (red.) 1974:8). 
Man mente med andre ord, at filmanalyser sat i samfundsfagligt perspektiv kunne afdække »de mystifikationer, forskydninger og tilsløringer« der var i filmene og dermed komme frem til »de virkelige forhold« og »frem til realitetserkendelse«. Selvom man inden for medieforskningen skiftede fokus fra værk til læser og dermed forlod forestillingen om, at man kunne afdække værkets egentlige, sande betydning - kan man i dag kynisk konstatere, at der grundlæggende intet er ændret ved de produktionsforhold, ved de herskende klassers interesser og magtforhold. Det er uforandret sådan, at medierne tilbyder en fortolkning af virkeligheden både i fiktion og i nyheder. $\mathrm{Og}$ at produktionsforhold og ansatte (oftest hvide med middelklassebaggrund) bevidst eller ikke bevidst vælger, hvordan de finder det relevant eller udfordrende at skildre virkeligheden.

Bourdieus argumenter er på mange måder en gentagelse af den marxistiske mediekritik.

Ved at lægge vægten på de kulørte nyheder, ved at fylde den kostbare tid med tomhed, med ingenting eller næsten ingenting, holder man de relevante informationer på afstand, som borgeren burde være i besiddelse af for at udøve sine demokratiske rettigheder

(Bourdieu 1998: 18).

Kulørte nyheder er historier om politikeres privatliv, sladder om »de kendte « eller andre nyheder, som er med til at underholde og servicere borgeren frem for at informere borgeren bedst muligt som forudsætning for at kunne handle i et demokratisk samfund (ibid.). I takt med, at den danske befolkning bliver sammensat af flere forskellige etniske grupper, som alle tillægger etnicitet stor betydning, er problemstillingen om repræsentation igen blevet aktuel. Nu handler det ikke om klassebaggrund, men om etnisk baggrund. Etnicitet og etnisk identitet tilskrives, såvel i Danmark som i det globale samfund, både personligt og politisk en uomgængelig betydning (Kelly 1998).

\section{Det sociale felt - journalistik}

Inden for antropologien (Barth 1994) og inden for sociologien (Bauman 1984) har man arbejdet meget med figuren det sociale felt. Derfor vil jeg kort skitsere, hvordan jeg finder Bourdieus (og Wacquants) arbejde med det sociale felt interessant i forhold til etnisk ligestilling og journalistik.
At tænke i felter er overordnet at tænke relationelt.

Den sociale verden består af relationer, ikke af interaktioner mellem aktører eller intersubjektive bånd mellem individer; men af objektive relationer der eksisterer uafhængigt af den enkeltes bevidsthed og vilje, med et marx-citat. (Bourdieu \& Wacquant 1996: 85).

At tænke relationelt i forhold til etnisk ligestilling og journalistik vil forenklet sige, at man ikke tillægger den enkelte journalist særlige negative perspektiver, eller mener at det er den enkelte lærer på uddannelserne, som har særlige nationale interesser, men derimod at lærere eller journalister må ses som subjekter, der befinder sig i nogle objektive strukturer. Subjekter har (også ifølge Bourdieu) et handlerum og er ikke ensidigt determineret af objektive strukturer (Bourdieu 1979/1986).

Bourdieu ser samfundet opdelt i en række sociale felter som f.eks. uddannelsessystemet, militæret, det kunstneriske felt og altså også det journalistiske felt (Bourdieu:1996/ 1998). De sociale felter er karakteriseret ved specielle egenskaber, logikker og kapitaler. Et felt er et socialt rum, hvor der hersker bestemte logikker, og hvor der stilles bestemte krav. I denne sammenhæng er det væsentlige, at man ikke kan forudsige hvilke logikker og værdier, som vil gøre sig gældende, det må undersøges empirisk.

\section{Hvordan afgrænser Bourdieu et socialt felt?}

Bourdieu finder det selv vanskeligt at afgrænse et felt, fordi man så at sige skal finde »noget«, der er formuleret inden for rammerne af feltet selv (Bourdieu \& Wacquant 1992/1996: 87). Men retningslinierne for, hvordan feltet afgrænses, lyder således:

1. Bestem feltets placering i relation til det overordnede magtfelt.

2. Undersøg de objektive relationer mellem forskellige aktører og institutioner, der fra forskellige positioner i feltet kæmper om den legitime og specifikke autoritet, feltet er bærer af.

3. Find frem til aktørernes habitus, de forskellige holdningssystemer, som aktørerne har internaliseret af en bestemt type sociale og økonomiske forhold, der udfoldet $\mathrm{i}$ et individuelt livsforløb har større eller mindre mulighed for at blive til virkelighed i et givet felt (ibid.:91).

Umiddelbart virker de tre forslag udmærket. 
Men skal man foretage en politologisk analyse af f.eks. journalistik i forhold til de eksisterende magtstrukturer? I givet fald med hvilken metode? Fra hvilket teoretisk perspektiv? Og med hvilken objektivitet? Hvordan afgrænse og finde frem til aktørernes habitus? Det giver Bourdieu ikke selv svar på. Derfor har jeg valgt kun at benytte disse spørgsmål som overordnede perspektiver og i stedet fremlægge en model for analysen, som forholder sig mere konkret til den empiri, jeg har til rådighed.

For at afdække det sociale felt vælger jeg at følge Bourdieus to læsninger.

Den første læsning er en form for social fysik, en objektiv struktur, der kan beskrives Udefra, og hvis fysiske elementer kan observeres og måles og kortlægges uafhængigt af de fremstillinger, individerne gør sig om samfundet (ibid.: 21).

Denne læsning svarer inden for tekstanalysen til det denotative niveau, et niveau hvor man søger at kortlægge, hvad alle kan være enige om. Ligesom i tekstanalysen er det i praksis ikke helt så objektivt, som det fremstår, idet det altid vil være fortolkeren, der fremlægger de træk, der senere vil blive lagt vægt på i analysen. I denne sammenhæng betyder det, at jeg fremlægger de objektive strukturer (f.eks. antal af ansøgere med etnisk minoritetsbaggrund), som jeg finder relevante i beskrivelsen af, hvilke logikker som er styrende inden for det sociale felt.

Den anden læsning, Bourdieu arbejder med, kan kaldes den social fænomenologiske. I denne læsning er det subjektets fortolkning af sin virkelighed, der er afinteresse (ibid.:21). Fra en diskursanalytisk tilgang ville man sige, at denne læsning svarer til de diskurser, aktørerne i det sociale felt konstruerer. I analysen stilles spørgsmålet: Hvordan konstruerer aktørerne virkeligheden omkring sig vedrørende etnisk ligestilling inden for det journalistiske felt?

Udover disse læsninger vil analysen inddrage Bourdieus begreber om kapital. De fire kapitaler udtrykker alle forskellige værdier, som er gældende inden for feltet, som blandt andet regulerer medlemmernes status. Bourdieu arbejder med fire kapitalformer nemlig den økonomiske kapital ${ }^{2}$, den kulturelle kapital ${ }^{3}$, den sociale kapital ${ }^{4}$ og den symbolske kapital ${ }^{5}$

Inspireret af Bourdieus kapitalformer fandt jeg i et tidligere studium i den danske folkeskole, at en af de distinktioner, der trådte frem, var, at de etnisk danske unge både $\mathrm{i}$ fritiden og $\mathrm{i}$ skolen havde et fortrin i forhold til eleverne med etnisk minoritetsbaggrund. Det fremgik ud fra en mindre analyse af folkeskolen som socialt felt (formålsparagraf, lærernes praksis og pædagogik), at skolen kunne betragtes som et flerkulturelt, men dansk defineret felt. Det fortrin, de etniske danske elever havde, kaldte jeg for national kapital og udviklede i forbindelse med interkulturel kommunikation national kapital som et analyseredskab, man kan anvende for at undersøge, om det nationale fungerer som en skjult dagsorden, en skjult værdi (Jensen 1998). I denne analyse vil jeg dels undersøge, hvorvidt økonomisk, kulturel, social og symbolsk kapital udtrykkes i materialet og altså også undersøge, om man inden for det journalistiske felt finder, at national kapital er på spil.

Sidste del af analysen består i at samle de forskellige tråde sammen til at vise, hvilken »logic of practice« (1980) der er inden for det sociale felt. Ifølge Bourdieu er det karakteristisk, at praksis ikke er logisk i rationel forstand, men bygger på andre former for logik. Ligesom feltet først kan bestemmes, efter man har fundet ud af dens udstrækning, forholder det sig med »logikkerne«. Man kan på baggrund af analysen foretage kvalificerede gæt, men man vil altid være henvist til kun at give sine bud på sammenhænge. Som i enhver tolkning overlades det herefter til forskeren at argumentere for rimeligheden af sine slutninger.

Tilbage er nu ganske konkret at finde frem til, hvilke nedslag i feltet analysen skal bygges på. Følgende er udvalgt.

1. Journalistuddannelsernes adgangskrav; for at belyse hvilke formaliserede krav der stilles til medlemmer, som søger om optagelse i det sociale felt.

2. Medieinstitutioner; for at finde frem til hvilke logikker og værdier der skaber mening i de etablerede medier. Dette er særligt interessant i forhold til ansættelser, ønske om »fair portrættering« og en mulig ændring af praksis.

3. Fagforening; for at undersøge hvordan den fagforeningsmæssige organiserede del af feltet forholder sig til etnisk ligestilling. Fagforeningen er desuden interessant, fordi den principielt bør repræsentere alle sine medlemmer lige og dermed i sit grundlag må arbejde med etnisk ligestilling. 
Styrken ved Bourdieus tilgang til sociologien er hans empiriske tilgang, hvori han kun tilskriver sine begreber relevans i forhold til konkret empiri. Men nok så vigtigt er det, at empiri kun bliver videnskabelig interessant, hvis det fremgår, hvordan den er fremskaffet, et synspunkt jeg tilslutter mig. Derfor redegør jeg i det følgende relativt detaljeret for mit eget normative grundlag for analyseprocessen.

\section{Objektivering af forskerperspektivet}

Artiklen bygger på empiri indsamlet i forbindelse med en undersøgelse foretaget for Nævnet for Etnisk Ligestilling. »Formålet med undersøgelsen er overordnet at belyse, hvordan danske medier kan udvikles til multietniske medier« (Jensen 2000). I undersøgelsen bruges betegnelsen multietniske medier som et pragmatisk redskab for et demokratisk ideal (Held 1987). Multietniske medier er kendetegnet ved den praksis 1) at medierne giver en ligeværdig repræsentation af alle etniske grupper, 2) at man i medierne kan aflæse, at journalister er bevidste om sprogbrug, der kan føre til stereotyper og xenofobi, 3) at etniske minoriteter ligestilles i alle roller i medierne, hvilket betyder, at de inddrages på lige fod som borgere, som publikum i underholdningsprogrammer og som eksperter i nyhedsudsendelser, 4) at man på programsiden har en reflekteret etnisk politik med henblik på at afspejle det multietniske samfund, 5) at man har en ansættelsespolitik, der fremmer etnisk ligestilling.

Inspirationen til disse idealer stammer fra de internationale tiltag, der er taget til »fair portrættering « en form for fælles retningslinier, man rundt om i Europa har arbejdet med inden for journalistikken (Melis 2000, Husband 1994, Singh 1995). Retningslinierne skal tænkes i forhold til en ændret praksis inden for journalistikken. I forhold til indsamlingen af det empiriske materiale kan man se en udvikling af multietniske medier som den underliggende diskurs, som alle journalister mere eller mindre bevidst har talt op imod. De interviewede, som delte dette ideal, har ikke følt det nødvendigt at argumentere for det nødvendige $\mathrm{i}$ en sådan udvikling, mens de journalister, som ikke delte dette ideal, har argumenteret for, hvorfor der ingen grund var til ændringer inden for området.

\section{Første lasning - objektive strukturer i feltet}

\section{Hvilke adgangskrav stilles der til feltet?}

Der er i dag tre journalistuddannelser i Danmark. Den »gamle« ved Danmarks Journalisthøjskole i Århus og de »nye« uddannelser i Journalistik ved henholdsvis Roskilde Universitetscenter og Syddansk Universitet. Adgangskravene er forskellige ved de tre uddannelser, men fælles for dem er at adgangskravene alle steder består af en mindre sprogtest og af større skriftlige opgaver, som skal besvares til en prøve. Cirka halvdelen af den fungerende journaliststand har imidlertid ikke en journalistisk uddannelse, men har fået erfaringer fra andre steder. Uddannelserne er afhængige af branchens accept, idet branchen skal levere praktikpladser, som er en forudsætning for, at uddannelsen kan fuldendes.

I de sidste år har der været ganske få ansøgere med etnisk minoritetsbaggrund ved de tre uddannelser. Vurderet på baggrund af navne har der i Århus været tale om omkring 10 ansøgere, hvoraf to er kommet ind. På de øvrige journalistuddannelser har der været optaget én person med etnisk minoritetsbaggrund på hver årgang.

Ingen af uddannelserne henvender sig specifikt til personer med etnisk minoritetsbaggrund, da de på nuværende tidspunkt ikke ser det som deres opgave.

Få uddannede journalister med etnisk minoritetsbaggrund Allerede på nuværende tidspunkt kan det konstateres, at der ikke er - og heller ikke i de næste 3-4 år vil være - ret mange journalister med etnisk minoritetsbaggrund. Der har kun været ganske få ansøgere og naturligt nok endnu færre, der kom igennem optagelseskravene. ${ }^{6}$

Penge er den vigtigste relation mellem medier og samfund Penge er den mest betydningsfulde relation mellem medieinstitutioner og det omgivende samfund. De kommercielle tv-stationer er helt afhængige af annoncører, hvilket betyder, at seertal får stadig større indflydelse. Konkurrencen kan aflæses i nyhedsudsendelser og programfladen, hvor nærhedsprincippet på bekostning af "public service« får større og større vægt (Hjarvard 1999).

Både DR og TV2 køber en stor del af deres udsendelser fra mindre produktionsselskaber. Mange af disse produktionsselskaber køres af tidligere 
medarbejdere de respektive steder. For ansøgere uanset etnisk baggrund - kan medieinstitutionerne fremstå som et lukket kredsløb, hvor man ikke kan få adgang uden at kende nogen, der kender nogen, altså svarende til Bourdieus sociale kapital.

\section{Få medieinstitutioner arbejder med etnisk ligestilling}

Kun DR har (for nylig) fået en policy for etnisk ligestilling. De øvrige medieinstitutioner ønsker umiddelbart ingen policy, men henviser til deres praksis: at de ansætter etniske minoriteter, når de er de bedst kvalificerede. Hver tv-station kan referere til en person med etnisk minoritetsbaggrund, som tidligere eller aktuelt har været ansat. DR og Aktuelt har modtaget »Stafetten « fra Nævnet for Etnisk Ligestilling, hvilket indebærer, at de forpligter sig til at gøre noget for udbredelse af etnisk ligestilling i år 2000.

Etnisk ligestilling i medierne skal ses i relation til, at nyhedsprogrammer i stigende grad beskæftiger sig med stofområdet. Stig Hjarvard har i sin rubricering af nyhedsemner rubriceret flygtninge/ racisme under samme kategori og i 1997 fundet følgende fordeling: DR1 bruger $7,2 \%$ af nyhedsudsendelserne på stofområdet, TV2 8,7\%, TV3 6,1\% og DR2 6,5\% (Hjarvard 1999: 266-267). Andre undersøgelser påpeger, at der i nyhedsformidlingen ikke er tale om alsidig dækning, men om ensidig fokusering på indvandrere som problem (Hussain et. al 1998).

Medierne skriver med andre ord meget om etniske minoriteter. Oftest som et problem for det danske samfund. Artiklen om indavl svarer helt hertil.

\section{Dansk Journalistforbund har nedsat en arbejdsgruppe} Dansk Journalistforbund (DJ) optager medlemmer, der arbejder journalistisk, uanset om de har en faglig journalistisk uddannelse. Ca. 50\% af medlemmerne af DJ er ikke uddannede journalister. DJ har repræsentanter i de forskellige uddannelsers bestyrelser. DJ har dermed en vis indflydelse på efteruddannelse og uddannelse.

Ved forbundets øverste myndighed delegeretmødet vedtog man »at nedsætte en arbejdsgruppe, der skal udarbejde forslag til en samlet politik med konkrete tiltag og målsætninger med henblik på etnisk ligestilling inden for faget.« Arbejdsgruppen har lagt op til, at man arbejder videre med følgende mål: at sammensætte faget så det afspejler befolkningssammensætningen, at arbejde for en bred rekruttering, at støtte initiativer der opgraderer og opkvalificerer ansøgere med anden etnisk baggrund til at klare relevante optagelsesprøver på samme betingelser som danske ansøgere. At undgår kvoteordninger, men acceptere positiv særbehandling i enkelte tilfælde.

Arbejdsgruppen anbefaler desuden, at man arbejder med etnisk ligestilling indenfor det uddannelsesmæssige område, det mediepolitiske område hvor arbejdsgruppen mener, at man bør rejse en debat om, hvorvidt DR og TV2 overholder deres Public Service forpligtelser på indvandrerområdet.

DJ har planlagt en konference, hvor etnisk ligestilling er på dagsordenen. Der er planer om at udgive en håndbog om anbefalede ord, udtryk og vendinger, og endelig har DJ arbejdet for, at et af sine medlemmer med etnisk minoritetsbaggrund blev genansat i DR, da indvandrerredaktionen blev nedlagt.

\section{Objektivering af det sociale felt journalistik}

Dansk Journalistforbund og DR har taget de første principielle overvejelser om, hvordan man i fremtiden vil og bør forholde sig til etnisk ligestilling. I DR er der imidlertid ikke afsat penge til at gennemføre særlige tiltag. Andre medieinstitutioner er imod retningslinier, men kan henvise til at have personer med etnisk minoritetsbaggrund ansat. Uddannelsesinstitutionerne står dermed som de eneste uden visioner om at arbejde for etnisk ligestilling. De henviser til, at etniske minoriteter kan og skal ansøge på lige fod med alle andre.

Af denne forste læsning fremgår det således, at der endnu ikke er taget nogle tiltag til ændring af etniske minoriteters adgang til det sociale felt eller strukturelle ændringer i de måder, man vil skildre etniske minoriteter på. Det fremgår, at der i dag er ganske få journalister og mediemedarbejdere (men der henvises meget til dem) ansat ved de etablerede medier. Det fremgår også, at stofområdet flygtninge/indvandrere dækkes massivt, hvilket vil sige, at etniske minoriteter sådan set er overrepræsenteret i medierne, men at der i dækningen oftest fokuseres på problemer relateret til gruppen (Hussain m.fl.1997, Hervik 1999, Yilmaz 1999), $\mathrm{og}$ at personer med etnisk minoritetsbaggrund kun sjældent optræder i andre professionelle roller (Christiansen \& Sell 2000).

Som nævnt er penge den mest betydningsfulde 
relation mellem medier og samfund. Det betyder konkret, at konkurrence mellem tv-stationerne spiller en stadig støre rolle, og at seertal dermed er blevet signifikante (Hjarvard 1999, Lund 1997, Pilger 1998). Konkurrencen mellem medierne er en konkurrence om seere. Men hvem er seerne? Annoncerne henvender sig ikke til »etniske andre«, i modsætning til andre lande. I Canada, England og USA er det tydeligt, at annoncørerne har indarbejdet etnicitet i deres segmentering. I indkøbskataloger, legetøjskataloger m.m. finder man oftest princippet om flest mulige etniske grupper inkluderet. En del skyldes lovgivning, mens en anden del utvivlsomt skyldes, at annoncørerne satser på at sælge produkter udfra livsstil og dermed vinder mest ved at gå på tværs af etniske grupper. Men sådan er det ikke i Danmark. Annoncørerne betragter tilsyneladende ikke indvandrere/flygtninge som en vigtig kundekreds sandsynligvis fordi annoncørerne ikke ved, at de etniske minoriteter ser meget dansk tv - særligt nyhedsudsendelser (Christiansen 2000). Det kan også skyldes, at arbejdsløsheden blandt etniske minoriteter er relativt stor, og at købekraften dermed er lille. Eller det kan skyldes det, at der fra et markedsmæssigt synspunkt befinder sig relativt få mennesker i Danmark med etnisk minoritetsbaggrund i den købedygtige alder.

Samler man nu de forskellige tråde, begynder mønstrene at dukke op. Hvis man skal kunne forklare den måde, hvorpå det sociale felt forholder sig til etnisk ligestilling, kan man sige, at etniske minoriteters generelt relativt svagere økonomiske og politiske position i Danmark gør det muligt for medierne/journalisterne at bruge de etniske minoriteter til at skaffe seere og kunder. At tale, skrive og vinkle historier om nogen, der ekskluderes - for dermed at inkludere sine brugere.

En del af fjernsynets symbolske handling, f.eks. på nyhedsområdet, består i at henlede opmærksomheden på hændelser, der er egnet til at interessere alle, og hvorom man kan sige, at de er omnibus - dvs. for alle. Omnibusnyheder er nyheder, der, som man siger, ikke må chokere nogen, der ikke sætter noget på spil, ikke deler, som skaber konsensus, interesserer alle, men på en måde så de ikke berører noget vigtigt (Bourdieu 1999: 17).

$\mathrm{Nu}$ kan man selvfølgelig ikke sige, at man ikke taler om noget vigtigt og ikke sætter noget vigtigt på spil, når man fylder sine politiske taler eller sine spalter med sager, der vedrører etniske minoriteter. Men alligevel vil jeg mene, at etniske minoriteter har samme funktion som omnibusnyheder, de kan hele tiden positioneres på en måde, som giver medierne de ønskede historier. I takt med at nærhedsprincippet har fået mere og mere indflydelse som journalistisk kriterium, fungerer etniske minoriteter tilsvarende fint $\mathrm{i}$ forhold til at skabe utryghed, moralsk panik etc. (Hall 1992), fordi man kan positionere fremmedheden i relation til den enkelte borger. Lokalaviser kan f.eks. beskrive, hvordan lokale beboere vil modsætte sig etablering af et nyt asylcenter, eller mod anbringelse af kriminelle asylansøgere. At etniske minoriteter fungerer som omnibusemne for såvel medierne som for mange politikere er efter min vurdering en af de mest betydningsfulde forklaringer på, hvordan det giver mening at tale om »indavl« på forsiden af Information.

\section{Anden lasning - en social fæenomenologisk}

Etniske minoriteter er velkomne på danske betingelser På alle tre journalistuddannelser udtrykkes det, at journalister med etnisk minoritetsbaggrund er velkomne, men at de kan og skal søge på samme vilkår som etnisk danske ansøgere. På journalisthøjskolen i Århus argumenterer man for, at prøverne er anonyme, hvilket stiller alle lige.

På de to nye uddannelser er der ikke anonymitet, da der indgår interviews ved optagelsesprøven, men ansatte på begge uddannelser udtrykker sig positivt over for ansøgere med etnisk minoritetsbaggrund. Der lægges dog ikke skjul på, at de studerende skal udlæres i dansk journalistik. Nu skal man ikke overse, at underviserne bruger betegnelsen »dansk journalistik« som beskrivelse af, hvordan reglerne på uddannelsesinstitutionen er. Regler, som i sig selv ikke behøver at være relateret til dansk kultur, men i samme grad til krav om f.eks. faglig stillingtagen til bestemte emner. F.eks. er det ikke et specifikt dansk krav at overholde deadlines, eller at kræve at en studerende forholder sig fagligt til et oplæg om religion. ${ }^{7}$

Det er fælles for udtalelserne (diskursen) ved de tre uddannelsesinstitutioner, at det er ansøgerne og ikke feltet, der skal tilpasse sig. 


\section{Medieinstitutionernes ord}

Vi tager de bedst kualificerede

Dette udsagn optræder ved alle de etablerede tvstationer. Uafhængigt af hinanden benytter alle samme argumentation. 1) tv-stationen tager de bedst kvalificerede ansøgere, 2) etnisk baggrund spiller ikke ind og 3) alle har nu (eller tidligere) haft medarbejdere med etnisk minoritetsbaggrund.

TV3 er en international virksomhed. Vi tager de bedste, vi tænker ikke så meget over, hvor folk kommer fra. Vi opererer multinationalt og internationalt. Vi er ikke opdraget til at tænke i etniske forskelle. Vi tager de bedst kvalificerede, det er det letteste. Vi har haft en pakistansk pige som studievært, vi har haft en græsk pige. I Robinson har vi begge gange haft deltagere med anden etnisk baggrund.

Hos TVDanmark lyder det:

Og i forhold til ansættelser - så har vi ikke nogen politik på det område. Men vi ansætter dem, der er kvalificerede. Den allerførste, der var ansat som studievært i Danmark med etnisk minoritetsbaggrund, hed Anilla. Hun var ansat hos os i et års tid. Hun arbejder i den skrevne presse nu. Hun havde etnisk pakistansk baggrund ... Vores problem er, at der er for få, der har gennemført en journalistisk uddannelse. Der er for få med de journalistiske kvalifikationer, vi efterlyser.

Og på TV2 er det informationsmedarbejderen, som skriftligt gav følgende formulering af TV2s etniske ligestillingspolitik:

TV2 har ingen fastlagte principper om etnisk ligestilling - heller ikke i forbindelse med ansættelser. Det interesserer os ikke, hvilken baggrund ansøgerne og medarbejderne kommer med. Vi skal blot have de bedste folk, hvad enten det er journalister, fotografer, teknikere, sekretærer eller direktører, lige som vi skal have de bedste nyhedshistorier, de bedste programmer og det bedste design. Hvem, der leverer programmer og design, er vi sådan set ligeglade med. En af dem, der var primus motor og art director i udviklingen af TV2's flotte design, var f.eks. iransk flygtning. Han havde de gode ideer - og så valgte vi at hyre ham til opgaven.

Når man på flere medieinstitutioner benytter udsagnet: »Vi tager de bedst kvalificerede«, og umid- delbart efter tilføjer, at man har haft en ansat med etnisk minoritetsbaggrund, så konstrueres implicit en anden forestilling: At det kun har været en enkelt gang eller to, at der har været en ansøger med etnisk minoritetsbaggrund, som var kvalificeret. Man kan underforstå, at medieinstitutionerne har taget alle de kvalificerede ansøgere, der var. At det ikke forholder sig sådan i praksis, kan man få indtryk af ved at tale med unge på lokalstationerne, som har søgt mange stillinger ved de etablerede medier. De bliver ikke betragtet som kvalificerede, selvom de f.eks. har en journalistisk uddannelse fra et andet land, har journalistisk erfaring, anden uddannelse etc. Dette skal ses i forhold til, at 50\% af de etnisk danske journalister ikke har en faguddannelse i journalistik. De er derfor ikke blevet afvist med henvisning til deres manglende uddannelsesbaggrund, men med begrundelser som: $» \mathrm{Du}$ vil have sværere ved at tale med kameramanden etc.«

Når man på medieinstitutionerne siger, at man slet ikke interesserer sig for ansøgernes etniske baggrund, taler man inden for en diskurs, som eksisterer i alle multietniske lande. I Danmark er den blandt andet udtrykt i folkeskolen, hvor nogle lærere (ud fra de bedste intentioner) erklærer, at de slet ikke ser børnenes etniske baggrund. For dem er alle børn ens. Denne gruppe lærere betragter deres egen farveblindhed som udtryk for deres interkulturelle kompetence. Selvom idealet i et multietnisk samfund netop er farveblindhed, så er det på nuværende tidspunkt kun som majoritetsmedlem, at farveblindhed giver positiv mening. Når folks etniske flade har betydning for alt i den verden, de omgives af, nytter det ikke, at man som professionel lader som om, det ikke eksisterer. Jennifer Kelly argumenterer meget overbevisende i sin bog, »Under the Gaze« - med den rammende undertitel: »Learning to be Black in White Society « - for, at observationen af etniske minoriteter er allestedsnærværende. Det påvirker alt, derfor kan hverken minoritet eller majoritet lade som om, det intet betyder, uden blot at reproducere de eksisterende dominansforhold (Kelly 1998).

\section{Journalistisk objektivitet}

På TV2 formulerede informationsmedarbejderen også selv skriftligt sit syn på, hvordan man i nyhederne arbejdede med etnisk ligestilling.

TV2's Nyhedsafdeling arbejder simpelthen journalistisk og skildrer virkeligheden, og NYHE- 
DERNE har ingen ønsker eller planer om at frelse verden eller redde integrationen. TV2 missionerer ikke. Det handler om at skildre virkeligheden - både når andengenerationsindvandrere står bag overfald, når danskerne diskuterer antallet af flygtninge og indvandrere, og når integrationen lykkes. Alle disse historier bliver skildret $\mathrm{i}$ NYHEDERNE. ${ }^{8}$

Denne udtalelse ligger forlængelse af forestillingen om farveblindhed. Det forudsættes, at det er muligt at sætte sig i en objektiv position, hvorfra man sagligt skildrer verden. Hermed hæver man det journalistiske håndværk op over både socialisering og diskurser. Citatets eget ordvalg dementerer imidlertid den forestilling. Det ses fra ordvalget »andengenerationsindvandrer og ved den meget almindelige modstilling mellem danskere og »de andre«. At diskurs har en betydning kan aflæses i ligheden i udtalelserne fra tv-stationerne.

\section{Vi vil ikke have retningslinier}

I det følgende fremgår det, hvordan man på forskellige tv-stationer argumenterer imod anbefalinger omkring »fair portrættering«. Man argumenterer for, at det er de klassiske nyhedskriterier, der skal gælde i dækningen af alle områder. TVDanmark er meget kritisk overfor indføring af formaliserede tiltag omkring etnisk ligestilling, som f.eks. anbefalinger om »fair portrættering«, som man f.eks. har i Holland og på BBC. ${ }^{9}$

Vi vil ikke have nogle retningslinier. Jeg vil ikke have dikteret, at nu skal vi bruge ordet »nydansker« samtidig med, at der er en interesseorganisation, som hedder nydansker, hvis politiske mål er, at vi skal sige nydansker. Så vil jeg heller sige 2. generationsindvandrere, selvom det måske ikke er helt korrekt og burde hedde »2. generations dansk-pakistansk«. Jeg vil bruge ordet nydansker, når det står i retskrivningsordbogen. At give retningslinier er for mig at foretage redaktionelle indgreb, som berører medarbejdernes integritet.

Journalisten demonstrerer, at han fra sit faglige perspektiv har taget stilling til f.eks. sit brug af betegnelsen 2. generationsindvandrer frem for betegnelsen nydansker. Han demonstrerer også kendskab til de bindestregs-betegnelser, som anbefales af flere forskere i dag (Mørch 1998, Jensen 1998), fordi man derved kan understrege, at etniske grupper har en relation til såvel det danske samfund som til et andet samfund. Retningslinier opfattes inden for denne forståelse som et brud på ytringsfriheden og som et overgreb i forhold til den faglige tradition, som foreskriver, at man ser en sag fra flere sider. Og dermed ikke følger bestemte interesser.

Set fra mit (kultursociologiske) perspektiv er det imidlertid pointen, at man som journalist må have skærpet sin bevidsthed om, hvornår kultur og socialisering spiller ind på de kriterier, man stiller for valg af ord. Valg af vinklinger og hvad man finder passende og afbalanceret. I forbindelse med rapporten, der ligger til grund for dette arbejde, fik jeg to rettelser fra personer med etnisk minoritetsbaggrund ind til manuskriptet. Den ene gjorde opmærksom på, at jeg brugte betegnelsen »Vi«, som om jeg talte til et fælles nationalt vi. Den anden bad mig om at ændre »drengen måtte ikke bade på grund af sin tro« til »drengen kunne ikke bade på grund af sin tro«. I den første sætning signalerer jeg, at drengen har et valg og vælger at følge sin religion. I den anden formulering har drengen ikke noget valg, hvis han er troende. Det var den sidste betydning, læseren med etnisk minoritetsbaggrund ville have frem. Min pointe er, at selvom jeg arbejder med dette stofområde på 10. år, vil det jeg skriver til enhver tid være præget af min sociale position, majoritetsmedlem, opdraget med kristendommen som et valg og ikke som et grundvilkår.

\section{Medierne er på vej med "fair portrettering"}

Danmarks Radio havde som den eneste medieinstitution (netop) formuleret det første udkast til en politik på området. Udtalelserne fra DR er et godt eksempel på, hvordan man taler (principiel) i enighed om at udvikle medierne til multietniske medier.

Vi har vedtaget et sæt etiske retningslinier efter forbillede fra, hvad der er i Sverige og Norge og ikke mindst BBC om portrættering af etniske minoriteter. Vi vil ud fra den kritik, der lyder, at medier generelt kun fokuserer på indvandrere, når det drejer sig om indvandrer/flygtningespørgsmål eller kriminalitet. Der er for mange eksempler på, at medierne, ud fra manglende omtanke eller ud fra fejlagtige oplysninger fra andre myndigheder i samfundet, kommer til at give sådanne skævvridninger.

I modsætning til alle hidtidige fremlagte citater 
»erkender« man i DR, at man tidligere har været på galt spor.

Nogle nyhedsformater kan vi ikke lave om på. Men man kan være meget opmærksom på at fjerne udtryk, der stempler. Det, der er vigtigst at rense ud, er de der automat-tillægsord og beskrivelser. Det er dét vi vil med vores etniske policy. Pas på, vær varsom. For ellers bliver vi ved med at køre med klicheer, klichebilleder i folks hoveder. Det er automat-ordene, vi skal have væk.

Der gives her et konkret eksempel på, hvordan man i praksis kan ændre ved mediernes fremstilling. Man kan sørge for at sætte en refleksionsproces i gang, så automat-ordene ryger ud.

Vi vil i DR Nyheder aktivt arbejde for at få det multikulturelle - multietniske - samfund repræsenteret $\mathrm{i}$ institutionen. Men vi er opmærksomme på, at det her er lige så vanskeligt, som da vi startede diskussionen om ligestilling [mellem $\mathrm{k} ø \mathrm{n}$ ] i 70'erne. Vi vil ikke begå de samme fejl. Her har vi et virkeligt dilemma; vi er overbeviste om, at det tjener både os, men ikke mindst den gruppe, vi taler om, at dem, vi skal have ansat, skal være mindst lige så dygtige som alle mulige andre.

Her gives det første tilsagn, og det eneste blandt samtlige tv-stationer om, at man aktivt vil arbejde for at få det multietniske samfund repræsenteret i institutionen. Men straks efter denne erklæring kommer forbeholdet: At det vil blive vanskeligt. Og at man må tage ved lære af de fejl, man gjorde, da kvinderne kom ind. Hvilke fejl, siges ikke. Men det antydes, at kvinderne ikke var helt så kvalificerede som mændene, og at det er den fejl, man ikke vil gentage. Uanset om det er den tiltænkte tolkning fra journalistens side, lades man tilbage med budskabet: De skal være mindst lige så kvalificerede, hvilket gør rekrutteringen meget svær.

Overordnet kan man sige, at DR-udtalelserne adskiller sig radikalt fra de før citerede, fordi de i udgangspunktet anerkender, at medierne, i hvert fald tidligere, har gjort sig skyldige i at bruge »automat-ord «, hvilket vil sige ord som »militante muslimer«, »2. generationsindvandrer«, »af fremmed herkomst« etc. Ligesom man erkender, at man ikke har formået at skabe en »fair portrættering«. Udtalelserne adskiller sig også ved et erklæret ønske om forandring i retning af multietniske medier. Men alligevel argumenteres der for, at »de nye journalister« skal være mindst lige så kvalificere- de. Hermed fastholder DR retten til at bestemme tempoet for udvikling af multietniske medier. ${ }^{10}$

\section{Giv plads til etniske minoriteter $i$ de etablerede medier}

De følgende udsagn står i modsætning til alle tidligere, som er optaget af, hvorvidt etniske minoriteter er kvalificerede til at blive optaget ved medieinstitutionerne eller ved uddannelserne. Her er man for det første ikke i tvivl om, at de etablerede danske medier ikke er multietniske eller multikulturelle. For det andet tager man for givet, at det er forhold i det danske samfund, de danske journalistuddannelser, medieinstitutioner og hos den etnisk danske befolkning, der skal ændres.

De danske medier er ikke multikulturelle, hvis man sammenligner med Sverige og Tyskland, der er langt mere flerkulturelle. Sverige har mange flere studieværter, der er farvede eller mørke. I Tyskland er en af de mest populære talkshowværter sort. I Sarajevo havde vi også allerede i '89 en sort studievært. Et andet eksempel på, at det ikke er flerkulturelt eller multikulturel, er, at man ikke går op i - på radioavisen f.eks. - hvordan udenlandske navne skal udtales. Alle navne udtales bare, som man vil gøre det på dansk. På BBC bruger de f.eks. meget tid på at udtale navnene, som man gør i det land eller på det pågældende sprog. Noget andet er, at man tekster alt for meget, hvad indvandrere siger. Det er i orden, hvis der er én, der er meget svær at forstå. Men hvis man tekster alt - også når folk taler godt - så bliver danskerne ikke tvunget til at lytte. De skal jo vænne sig til at lytte til accent. Det er de ikke så gode til. Derfor må man bruge medierne til at vænne dem til at lytte til accent. Jeg tror, der går et stykke tid, før der sker noget.

Journalisten (som har etnisk minoritetsbaggrund) fremhæver, at etniske danskere skal vænne sig til de nye forhold. De skal vænne sig til accent. Citatet illustrerer samtidig, hvordan det er i de helt konkrete valg i en produktion, man beslutter, hvem der skal betragtes som inkluderet i det danske, som en person man skal kunne forstå, og hvem der betragtes som nogle, der ekskluderes, man ikke kan forstå. Tekstning regulerer f.eks. også, hvor meget dialekt man vil have i samfundet, samt den position den interviewede betragtes med inden for feltet. Et af de mest gennemgående problemer omkring sprog og identitet er etniske danskeres mishag ved accent. På grund af den historiske luk- 
kethed og den mulighed, man har gennem opbygning af det danske, lidenhed og storhed, har sproget som indfødt fået en enorm betydning. En betydning som også smitter af i forhold til forestillinger om, hvor godt man skal beherske det danske sprog for at kunne blive f.eks. studievært.

Etnisk ligestilling er vigtig, fordi indvandrere bruges som historie hver dag. Når journalisterne insisterer på, at det er så vigtigt et stofområde, så må man sørge for, at journalisterne selv får et ordentlig kendskab til, hvad man skal gøre. De må lære os noget på uddannelserne. Man må efteruddanne de ældre journalister, og man må sørge for at rekruttere flere, så der bliver flere ansatte, så der kommer flere forbilleder for de unge.

Også i dette udsagn argumenterer journalisten for, at det er det danske samfund og dets institutioner, der må forandre sig. Der lægges også vægt på, at man må sørge for forbilleder for etniske minoriteter, og at det netop kan gøres gennem medierne.

Hvis vi nu sender blikket tilbage til avisartiklen om indavl, kan man sige, at journalisten bag artiklen repræsenterer det synspunkt (den diskurs), at det normale er det danske, og at etniske minoriteter beskrives i forhold hertil. Det er indvandrerne, som selv skaber problemerne, fordi de gifter sig med hinanden mod bedre (lægelig) vidende. Som en lille reminder om, at repræsentativitet alene ikke af sig selv ændrer en vinkling, kan man lægge mærke til, at selvom der optræder en læge med etnisk minoritetsbaggrund i artiklen, citeres han mindst lige så meget om sit eget ægteskab, hvilket betyder, at hans profession træder i baggrunden.

\section{Dansk journalistforbund har et medansvar for en bredere rekruttering}

Arbejdsgruppen, nedsat af DJ, udtrykker interesse for, at journalistfaget i fremtiden kommer til at afspejle den danske befolkning. DJ udtrykker, at de har et medansvar for at få faggruppen til at repræsentere befolkningen. »Problemet« med for få ansøgere med etnisk minoritetsbaggrund søges løst ved særlige kurser, som kan opkvalificere potentielle ansøgere, så de kan komme op på samme niveau som »danskere«. Inden for fagforeningens ordvalg anvender man altså også den udbredte modsætning mellem etniske minoriteter og danskere (danske statsborgere kan godt have etnisk minoritetsbaggrund).

I denne anden læsning, som lægger vægt på de subjektive beskrivelser af feltet, har jeg fundet frem til forskellige overordnede fortolkninger eller diskurser med betydning for etnisk ligestilling. Stærkest virkede udsagnet om, at alle ansøgere skal være (mindst) lige så kvalificerede som ansøgere med etnisk dansk baggrund. På medieinstitutionerne tillægger man ikke etnicitet betydning, men betragter snarere sig selv som farveblinde. På tværs af alle udtalelser går det igen, at kvalifikationer betragtes som objektive størrelser, man kan diskutere. I DR erkender man, at nyhedsdækningen tidligere har været på galt spor. Fra journalister med etnisk minoritetsbaggrund udtrykkes det, at man ønsker, at forandringen skal tage afsæt i det journalistiske felt. Samtidig er man overbevist om, at der findes kvalificerede ansøgere med etnisk minoritetsbaggrund.

\section{Hvilke krav stilles ved optagelsesproven?}

Prøven i Århus er anonym. I bedømmelsen kan ingen se, hvem der har skrevet opgaven, hvilket betyder, at alle principielt vil blive læst på samme måde.

For at få adgang til et felt skal den enkelte være udstyret med bestemte kvalifikationer og egenskaber. Et af målene med den sociologiske forskning er at finde ud af, hvilke træk og egenskaber der giver adgang og har gennemslagskraft, det vil sige hvilke specifikke kapitalformer, der har gyldighed på hvilke områder. Her står man overfor en hermeneutisk cirkel. For at konstruere feltet er man nødt til at bestemme de specifikke kapitalformer, der har gennemslagskraft, og for at konstruere systemet af kapitalformer er man nødt til at kende feltets særlige logik. Det er en lang og besværlig proces, hvor man konstant bevæger sig mellem to poler (Bourdieu \& Wacquant 1996: 94).

En del af undersøgelsen om etnisk ligestilling i medierne bestod af en analyse af optagelsesprøven ved Danmarks Journalisthøjskole i Århus fra 1994 til 1998 (Jensen 2000b). Jeg vil i det følgende først gøre rede for, hvilke almene værdier og logikker som fremgår af opgaveformuleringerne og herefter se på analysen med henblik på national kapital. Er der dele af opgaveformuleringer og valg af emner og vinkler, som peger på særlige nationale værdier? I analysen spurgte jeg: »Hvilken viden og kvalifikationer ønsker man, at ansøgeren er i besiddelse af?«, »Er der træk ved opgaveformuleringer, der kan gøre optagelsesprøven vanskeligere 
for ansøgere med etnisk minoritetsbaggrund end for ansøgere med etnisk dansk baggrund? «11

Overordnet viste analysen, at man ved journalistuddannelsen i Århus forudsatte, at ansøgerne havde følgende viden og kvalifikationer. De skulle 1) være $\mathrm{i}$ besiddelse af en bred, aktuel landspolitisk viden, herunder et vist kendskab til kommunalreformer, lokalpolitik mm., 2) være i besiddelse af en bred viden om aktuelle udenlandske politiske forhold, herunder især indgåelser af fredsaftaler, krige og konflikter (traditionelle 3. verdens nyheder), 3) de skulle have et vist niveau af »almen viden « om danske forhold, hvilket vil sige et sprogligt kendskab til ord og vendinger, et kendskab til samfundsforhold, et kendskab til finkultur mm. Generelt gælder det om den brede politiske viden, der efterspørges i opgaveformuleringerne, at de er mediebaserede og kan erhverves ved at læse, se og lytte især til nyhedsmedier. En af logikkerne bag optagelsesprøverne er altså, at man kan læse avis og huske, hvad man har læst. Herom skriver Bourdieu meget rammende.

For journalisterne er avislæsningen en uomgængelig aktivitet og presseoversigten et arbejdsredskab: for at vide hvad man skal vide, hvad de andre har sagt. Det er en af de mekanismer, der afføder ensheden af de præsenterede produkter (Bourdieu 1998: 25)《.

Sammenholdes prøverne ved alle tre journalistuddannelser kan man sige, at man alle steder lægger stor vægt på håndværksmæssige kvalifikationer. Ansøgerne skal demonstrere 1) at de kan følge en bunden, skriftlig opgavebeskrivelse, 2) at de kan bearbejde og vinkle forskelligt skriftligt såvel som videooptaget materiale og formidle det inden for en afgrænset tidsperiode, 3) at de kan formulere sig i et præcist sprog, der svarer til den stillede opgave. At kunne sit håndværk er en central værdi ved adgangskravene. En værdi der fremgår, når journalisterne holder fast i deres faglige selvforståelse; at det er muligt at vinkle sig til objektivitet. De specifikke former for kapital, man skal være i besiddelse af for at få adgang til det journalistiske felt gennem uddannelserne, er knyttet til at kunne reproducere journalistikken, sådan som man tidligere har gjort. Det betragtes som en kvalifikation at være interesseret i mediernes fremstilling af virkeligheden og at kunne huske navne, personer, og i øvrigt lægges der vægt på håndværksmæssige kvalifikationer.

\section{Er national kapital et adgangskrav?}

I forhold til etnisk ligestilling er hovedkonklusionen på analysen af optagelsesprøven, at opgaveformuleringerne generelt ikke er vanskeligere for ansøgere med etnisk minoritetsbaggrund, men formuleringerne er på den anden side heller ikke tænkt i forhold til det multietniske samfund. Der er en mangel på spørgsmål, der afspejler det multietniske samfund. Desuden er der visse steder i opgaveformuleringerne en stereotyp kulturel forudforståelse af andre kulturer, som fra et fagligt perspektiv ikke er tilfredsstillende.

Ved optagelsesprøven i 1998 fremlægger Vibeke Sperling f.eks. et foredrag, som ansøgerne skal referere sagligt og korrekt. I foredraget fremlægges imidlertid nogle synspunkter, som kan fortolkes som en ensidig kritik af forholdene i Rusland og det levede liv for Ruslands kvinder. Sperling fremfører f.eks., med en politikers udsagn som dokumentation, at mændene drikker meget, at der slås 15.000 kvinder ihjel hvert år i husspektakler, og at kvinder er seksuelt undertrykte. I umiddelbar forlængelse heraf fortælles det, at der kun findes to krisecentre for voldsramte kvinder. Det ene center er støttet af Danmark, hvilket understøtter den nationale vinkling (referatopgave 1998). Sperlings foredrag kan gøre det vanskeligere for en ansøger med etnisk minoritetsbaggrund af flere grunde. For det første kan ansøgeren blive »forført« til at markere en stillingtagen til den provokerende form frem for at referere sagligt, og for det andet er det ikke sikkert, at en ansøger med etnisk minoritetsbaggrund har samme kriterier for, hvad der er væsentligt omkring køn og kultur, hvilket igen får indflydelse på, hvorvidt et referat bliver bedømt som »ikke korrekt refereret« (Katz \& Liebes 1993, Jensen 1991, 1998).

Ogsåi 1998 finder man en vis stereotypificering. Iopgaven med 60 aktualitetsspørgsmål er udlandet primært repræsenteret ved spørgsmål, der forholder sig til politiske konventioner, krige, fredsaftaler og naturkatastrofer. F.eks.: »Hvilken voldsom begivenhed fandt sted i Egypten?« Svarmulighederne er: »drukneulykke«, »jordskælv«, »militærkup«, »dæmning går over sine bredder«, »turister dræbt ved massakre? « ${ }^{12}$ Udlandet og andre kulturer indgår endvidere som »svarmuligheder « på noget, der er »langt ude« i forhold til en dansk virkelighedsopfattelse. »Hvad er en Ebola?« Svarmulighe- 
der: »en sydamerikansk lasso«, »en livstruende virus«, »en sydspansk dans«, »et kunststof udviklet fra kautsjuk « eller »hovedstaden i Zambia « ${ }^{13}$

Brugen af disse næsten faste stereotypier om 3. verdens lande vidner om, at opgavestillerne enten har ønsket at markere danske/vestlige værdier og accept af den fungerende nyhedsdækning af 3 . verden, eller at opgavestillerne ikke har reflekteret tilstrækkeligt over, hvilke forestillinger om 3. verden som opretholdes ved at vælge disse svarmuligheder.

Et sidste sted fra optagelsesprøverne, som peger på et normativt grundlag, er en opgaveformulering om flygtningepolitik, som adskiller sig fra de andre. Spørgsmålet lyder: »Danmark har i de seneste år gennemført en række stramninger i flygtningelovgivningen. Beskriv de vigtigste baggrunde for denne udvikling« (1994). I denne formulering ligger det implicit, at der er enighed om, at det er nødvendige stramninger. Hvis opgaveformuleringen skulle have været identisk med de øvrige, skulle man have brugt en formulering som f.eks.: »beskriv de forskellige politiske begrundelser for disse stramninger af flygtningeloven.« Det er netop i mindre sproglige formuleringer som disse, at man kan øjne det normative grundlag, og også på dette niveau man kan undersøge, om opgavestillerne har været fagligt bevidste om deres formuleringer.

Af analysen fremgår det således, at optagelsesprøven enkelte steder indeholdt forenklede negative beskrivelser af andre lande og kulturer, hvilket kan gøre en referatopgave vanskeligere. Men hvad analysen også viser er, at man ikke betragter det som en kvalifikation at have viden om kultur, etnicitet etc. Man har f.eks. ikke mange navne med andet etnisk oprindelse end dansk. Man stiller ikke krævende spørgsmål, som forudsætter en faglig viden eller faglig interesse for integrationslov etc. Et forhold der skal ses i forhold til den store nyhedsinteresse, der er om stofområdet indvandrer/flygtninge.

Skal man være i besiddelse af national kapital for at komme ind på journalistuddannelserne i Danmark? Overordnet må man sige, at der er mange opgaver, der bygger på viden i medierne og på ansøgerens evne til at følge konkrete opgaveformuleringer. Alligevel spiller national kapital en rolle i opgaveformuleringerne som vist ovenfor. Og man kan sige, at national kapital spiller ind, når man fra uddannelsernes side ikke beskæftiger sig fagligt med det multietniske samfund. Desuden har ingen af de eksisterende journalistuddannelser endnu foretaget særlige tiltag for at rekruttere etniske minoriteter eller for at bibringe uddannelserne en faglighed omkring kulturforståelse, etnicitet og menneskerettigheder. Det kan tolkes som udtryk for, at national kapital findes og fungerer i praksis inden for uddannelsesinstitutionerne.

\section{Er national kapital en vardi ved de etablerede medieinstitutioner?}

Som det fremgik af de tidligere udtalelser fra journalister ved de etablerede medier, kunne alle referere til en person med etnisk minoritetsbaggrund i tilknytning til deres tv-station. Men samtidig refererer journalistiske medarbejdere på lokalstationerne til mange afslag på stillinger ved de etablerede medier. En af begrundelserne lyder, at journalisten på grund af sin etniske baggrund vil have sværere ved at kommunikere f.eks. med kameramanden etc. Med mindre en sådan formodning er funderet i konkrete dårlige erfaringer med interkulturel kommunikation er der tale om en formodning, som bygger på tilstedeværelse af national kapital.

Men også inden for de etablerede tv-stationer udtrykker journalister med etnisk minoritetsbaggrund kendskab til en udvælgelsesprocedure, som er betinget af etnisk baggrund.

Hvis der er en udlænding og en dansker, der er lige dygtige til deres fag, så tager de danskeren. Det gør ikke noget. Det bliver vi ikke kede af. Sådan er det. Men det, vi ikke kan lide, er når vi slet ikke bliver bedømt, men man bare tager os fra på grund af vores navn eller hudfarve.

Set i forhold til det samlede sociale felt er det interessant, at journalisten faktisk accepterer en forskelsbehandling, som kun er begrundet i nationalitet. Selvom journalisten ikke selv tilslutter sig en sådan værdi, mener han, at denne praksis finder sted.

\section{Hvilke vardier belønner fagforeningen?}

Kritisk journalistik

Hvilke idealer, man har inden for et felt, kan blandt andet aflæses ved de måder, man berømmer hin- 
anden på. Det kan f.eks. gøres ved uddeling af legater eller anden hædersbevisning. Inden for det journalistiske felt kan man se, at kritisk journalistik, undersøgende journalistik, afslørende journalistik har høj værdi i det journalistiske felt. Der uddeles priser af Dansk Journalistforbund for journalistisk arbejde, der på disse områder viser en særlig kvalitet. Kritisk, undersøgende og afslørende journalistik er en del af værdierne i den journalistiske selvforståelse - sådan ser god journalistik ud. Det kan slås fast, at det betragtes som en kapital at udøve kritisk journalistik, som får betydning i samfundet.

\section{Ingen priser omkring fair portrettering}

DJ ville ikke stifte en pris for god journalistik vedrørende etniske minoriteter. DJ fandt, at det var en politisk sag, hvordan man beskrive etniske minoriteter og ville på den måde ikke være part $\mathrm{i}$ sagen. Denne reaktion står i modsætning til dels verdensorganisationen, hvor man i flere år har arbejdet med »fair portrættering « og med priser og med de tiltag, der er kommet fra EU, hvor man også arbejder med forskellige former for »fair portrættering«. På den ene side ser man det i fagforeningen som en kapital at udføre kritisk journalistik. Men i modsætning til andre lande betragter man inden for fagforeningen etnisk ligestilling som et særligt politisk område, hvilket er begrundelsen for, at man ikke vil belønne artikler, som særligt kvalificeret har arbejdet med etnisk ligestilling. Flere forhold spiller ind i denne ambivalens, men et af dem er at emnet omkring etnisk ligestilling berører national kapital.

Er national kapital så også en værdi i artiklen om indavl? I en analyse af teksten bliver det klart, at der er to grupper repræsenteret i artiklerne, indvandrerne som gifter sig med deres fætre og kusiner, og deres børn som får problemer i skolen. På den anden side har vi danskere, som der ikke hæftes problemer på, men som tværtimod positioneres som de gode undervisere, som er blevet bedre til at finde svage danske børn. Dette bliver igen brugt til at forklare antallet af danske børn i specialklasserne. Lærernes manglende kompetence i at undervise tosprogede børn nævnes slet ikke i artiklen. De etnisk danske lærere kritiseres f.eks. ikke i artiklen for ikke at være $\mathrm{i}$ stand til at forhindre så stort et antal elever, som går til specialundervisning.

\section{Logikker}

Practice has a logic which is not that of the logician. This has to be acknowledged in order to avoid asking of it more logic than it can give, thereby condemning oneself either to wring incoherences out of it or to thrust a forced coherence upon it

(Bourdieu 1990: 86)

Med dette forbehold fremlægger jeg i det følgende mine bud på, hvilke logikker der er bærende inden for det journalistiske felt.

\section{Adgangskravene bor fastholdes}

Ved de tre uddannelsesinstitutioner er det den overordnede logik, at ansøgere skal være i stand til at blive journalister enten som tidligere eller på de nye uddannelser med en mere akademisk tilgang. Dette skal dog ikke gå ud over det journalistiske håndværk, som blandt andet testes ved skriftlig sproglig færdighed, grammatik og formuleringsevne. Logikken på uddannelserne er, at kandidaterne skal tilpasses branchens krav. I forhold til etnisk ligestilling er der endnu ikke taget nogle særlige tiltag ved de tre uddannelser. Logikken omkring etnisk ligestilling er formuleret mere eller mindre eksplicit. Alle kvalificerede ansøgere er velkomne, uanset etnisk baggrund. Uddannelsesinstitutionerne ser ikke sig selv som del af en samfundsmæssig forandringsproces, hvor man må ændre på adgangskravene, som man tidligere gjorde i et forsøg på at få flere kvinder til at komme ind på Journalisthøjskolen. Ved optagelsesprøverne bliver ansøgerne bedt om at skrive om etniske minoriteter, men bliver i meget ringe grad bedt om at demonstrere fagligt kendskab til menneskerettigheder, flygtningepolitik, kulturforståelse. Logikken kan beskrives som en fastholdelse af status quo og ved et fravær af tiltag svarende til de samfundsmæssige forandringer.

\section{Logikker i medieinstitutionerne}

\section{Konkurrence er uundgåelig}

Den mest gennemgående logik i medieinstitutionerne er mediernes indbyrdes konkurrence om seernes gunst. Konkurrencen påvirker alt fra sendeflade til logo, og i forhold til etnisk ligestilling betyder konkurrencen, at medieinstitutionerne bruger etniske minoriteter som omnibus-emne. 


\section{Ytringsfriheden kommer forst}

En anden meget gennemgående logik er, at en del journalister ikke ønsker særlige retningslinier, som kan være med til at skabe en »fair portrættering«, fordi de finder, at det tilsidesætter ytringsfriheden. Denne logik finder man også i resten af Norden, hvorimod man i andre dele af verden har arbejdet med retningslinier i mange år. Fastholdelsen af ytringsfriheden og dennes suverænitet skal ses som udtryk for en stærk national identitet eller, som jeg tidligere har været ind på, som udtryk for, at der i felter findes en national kapital.

\section{Journalistik er et håndvark}

Blandt journalister betragtes medieforskere ofte med en vis mistro. Journalister har traditionelt konstrueret deres faglige identitet ud fra en forestilling om, at journalistik var et håndværk, og at man ikke behøvede at have en specifik faglig viden om forskellige områder, men at man gennem sit håndværk skulle være i stand til at forholde sig objektivt til et stofområde.

Denne logik hviler på en forestilling om, at man kan forholde sig objektivt til virkeligheden omkring sig.

\section{Kvalifikationer er objektive}

$» \mathrm{Vi}$ tager de bedste!« Et ganske indlysende ansættelseskriterium, men det bygger på forestillingen om, at kvalifikationer er objektive, og at det er muligt for medieinstitutionerne at sætte sig ud over f.eks. ansøgerens etniske baggrund. Når det fremstår så indlysende, er det dels fordi, logikken også gælder inden for andre områder - at det er muligt at opstille objektive udvælgelseskriterier, og dels fordi det er en problemstilling, der udelukkende ses fra et majoritetsperspektiv. ${ }^{14}$

Indenfor det journalistiske felt er forestillingen om »lige kvalifikationer« så stærk, at den går på tværs af samtlige udtalelser. Alle taler om kvalifikationer som objektive størrelser, man kan opnå eller have. Logikkens selvfølgelighed omkring kvalifikationer må imidlertid forstyrres. Man må til stadighed problematisere, hvad det er for kvalifikationer, man efterlyser. Gør man ikke det, kommer forestillinger om kvalificering helt til at skjule tilstedeværelsen af national kapital inden for feltet.

Samtidig undgår man at diskutere, hvem der skal definere, hvornår personer er lige kvalificerede. Og man undgår at diskutere, om fravalg af andre kvalifikationer, som f.eks. at have et andet lands sprog som modersmål, at have politiske kontakter og at kunne orientere sig ubesværet i et andet lands medier, ikke også kan betragtes som kvalifikationer. Sidst undgår man at diskutere det fravalg af erfaringer, som er knyttet til at være opvokset i det danske samfund som etnisk minoritetsmedlem.

\section{Fagforeningslogikker}

Som før nævnt behøver man ikke at være faguddannet journalist for at blive optaget i Journalistforbundet. Man kan se det som en konsekvens af, at faget betragtes som et håndværk, og har man bevist, at man kan leve af at skrive, har man retten til at komme ind i forbundet. Det er ganske enestående, at et fagligt felt ikke udelukkende kontrolleres gennem fagets egne uddannelser (gymnasielærere skal f.eks. have taget bestemte universitetsuddannelser og må ikke være autodidakte).

For etniske minoriteter betyder dette, at der i dag er åbenhed for de mange unge med etnisk minoritetsbaggrund, som har taget en længerevarende uddannelse. De har mulighed for at søge ind ved medierne.

\section{Forklarer logikkerne så artiklen om indavl?}

For sidste gang skal blikket nu rettes mod artiklen om indavl. Det skal nu vise sig, hvorvidt denne Bourdieu-inspirerede tilgang har været i stand til at kaste et andet lys over artiklen. Om det nu er muligt at forklare, hvorfor artiklen ser ud, som den gør.

For det første kan man forklare artiklens blotte eksistens på forsiden, (med en påstand, som blev dementeret dagen efter), med den mest betydningsfulde logik: konkurrencen. Medierne befinder sig i en konkurrencesituation, så journalisten må gøre, hvad der står i vedkommendes magt for at producere nyheder, der kan sælge. Selvom det er en værdi inden for feltet at være kritisk journalist, er hensynet til konkurrence og produktion af daglige historier størst.

For det andet holder journalisten ytringsfriheden i hævd. »Sandheden« kommer nu frem, der røres ved et tabubelagt emne. Journalisten benytter sig af ytringsfriheden og fremsætter nogle 
påstande omkring formodninger om indavl, men samtidig kan artiklen som helhed ikke sige sig fri for at være skrevet over en dualistisk skabelon, hvor de gode, kloge, handlende aktører er etniske danskere, mens dem med de forkerte giftetraditioner og forældrene til de overrepræsenterede problembørn er etniske minoriteter.

Noget af det, der i forhold til etnisk ligestilling og »fair« portrættering går galt i artiklen, er en sammenblanding af de forskellige logikker. En tolkning kan være: Journalisten er i konkurrence, ønsker at bruge sin ytringsfrihed, skrive kritisk og tage nye sider af indvandrerdebatten op, men har samtidig en håndværkertilgang, som forhindrer, at hun foretager den refleksion, der gør det muligt for hende at se, hvordan hendes egen nationale identitet er med til at vinkle artiklen og med til at bestemme, hvilke spørgsmål hun finder på at stille.

\section{Konklusion}

Analysen af feltet peger på følgende hovedkonklusioner: For det første at etniske minoriteters største betydning i de eksisterende medier er, at de bruges som omnibusemner, det vil sige emner, som medierne vælger for at gøre flest muligt i målgruppen interesseret. Og da etniske minoriteter såvel numerisk som i praksis udgør en så lille økonomisk gruppe, vælger man inden for det journalistiske felt at skrive om »dem« $\mathrm{i}$ stedet for at inkludere »dem«.

En anden gennemgående værdi inden for feltet er, at der tilsyneladende også i medierne er en national kapital på spil, som gør, at journalister med etnisk dansk baggrund umiddelbart betragtes som mere kvalificerede til at varetage jobbet som journalist. National kapital sætter sig igennem ved ansættelsessituationer, ved uddannelsernes manglende engagement $\mathrm{i}$ at tiltrække ansøgere uden denne kapital og ved den manglende anerkendelse af journalistuddannelser erhvervet i udlandet.

Samtidig med tilstedeværelsen af den nationale kapital er der inden for det journalistiske felt en stærk diskurs om, at man ansætter den mest kvalificerede ansøger, og at man end ikke skeler til personens etniske baggrund. I forlængelse heraf dokumenterer man sin påstand ved at henvise til en ansat, man tidligere har haft - eller en nuværende ansat - som har etnisk minoritetsbaggrund. Logikken bag disse diskurser er imidlertid, at kva- lifikationer er objektive størrelser, og at alle har lige adgang til feltet. Hermed er bolden spillet tilbage til de etniske minoriteter, som kritiseres for ikke at søge ind ved journalistuddannelserne. Det journalistiske felt sender hermed ansvaret for ændringen af feltet over til dem, de selv skal give adgang. Det må umiddelbart betyde, at feltet på nuværende tidspunkt ikke i praksis har taget ansvar for sin del af udviklingen af et multietnisk journalistisk felt, som afspejler samfundet.

Hvis det journalistiske felt skal udvikle sig til at rumme multietnisk journalistik, skal man tale mindre om opkvalificering af journalister med etnisk minoritetsbaggrund og tale mere om at opkvalificere den faglige viden om stofområdet. Jeg taler altså for en fagliggørelse af journalisters forstålse af »etniske andre«, etniske minoriteter eller viden om national identitet, etnicitet og sprog. En fagliggørelse vil sætte sig igennem ved adgangskravene og vil opkvalificere debatten i medierne, så der argumenteres på baggrund af en faglig viden frem for journalistens personlige eller politiske holdning.

\section{Noter}

1. Analysen bygger på en større empirisk undersøgelse foretaget for Nævnet for Etnisk ligestilling indsamlet $i$ efteråret 1999. Rapporten udkom november 2000.

2. Som ikke kræver nærmere forklaring.

3. Er den kapital man opnår gennem akademiske institutioner som universiteter, lærerhøjskoler etc.

4. Som forenklet kan beskrives som en værdi, man har, når man kender mennesker $i$ et socialt netværk, som kan hjælpe en til at opnå sine mål. Denne kapital er (uofficielt) central ved mange ansættelser på det danske arbejdsmarked og efter sigende også en vigtig adgangsbillet til de etablerede medier. Det er ikke mindst et rygte, som gælder DR, at man uanset etnisk baggrund skal kende nogen, der kender nogen i miljøet for at komme ind.

5. Kan beskrives som den måde, de forskellige kapitaler kan udtrykkes. Har man megen økonomisk kapital, kan man vise det ved en dyr bil, en dyr villa etc. Den kulturelle kapital fremvises gennem brug af titler, den sociale kapital udtrykkes f.eks. gennem afholdelse af receptioner med betydningsfulde mennesker.

6. Flere journalister med etnisk minoritetsbaggrund sikrer ikke automatisk, at der bliver lagt en anden vinkel på stofområdet, eller at alle etniske grupper vil blive repræsenteret ligeligt. For at skabe en sådan forandring må der på alle niveauer i medierne finde en professionalisering sted, således at journalister forholder sig fagligt til stofområdet.

7. Alligevel bliver det i forbindelse med uddannelseskrav nødvendigt, at man på uddannelsesinstitutionerne ta- 
ger stilling til, om man skal stille samme sproglige krav til alle studerende, uanset om de har dansk som 2. sprog.

8. Citatet fortsætter således: »TV2 har bragt masser af historier, hvori medvirkede etniske minoriteter, der er særdeles velfungerende,

- bl.a. en række succeshistorier om familier og personer med anden etnisk baggrund, som fungerer fremragende socialt, uddannelsesmæssigt og arbejdsmæssigt, - om fædregrupper, der gør et solidt stykke arbejde,

- om flygtninge, indvandrere og andengenerationsindvandrere, der kommenterer politiske tiltag (herunder statsministerens nytårstale)

- om erhvervslivet, der ikke løser opgaven godt nok med at ansætte etniske minoriteter, og

- om Dansk Industri, der advarer mod fremmedgørelse af indvandrere og manglende ansættelser af etniske minoriteter.

Men det er også historier om store boligområder med manglende integration og historier om volds- og berigelseskriminalitet blandt unge med indvandrerbaggrund. For det er også en del af virkeligheden. Det er nyhedshistorier, som laves efter én eneste vurdering: Den journalistiske vurdering af hvad der er væsentligt og relevant at fortælle seerne. Og sådan arbejder aviserne også: Med journalistisk prioritering og vinkling af de nyheder, som læserne skal præsenteres for« (Jensen 2000b).

9. Det er overordnede retningslinier for, hvordan man bedst sikrer, at alle samfundets borgere repræsenteres lige.

10.DR genoptog f.eks. programmet »Flygtning eller hvad?« på trods af massiv kritik af programmets negative konsekvenser for de medvirkende flygtninge, ligesom selve konceptet blev stærkt kritiseret. DR producerede selv en kritisk dokumentarudsendelse om programmet, men foretager efter min vurdering ikke en »fair portrættering«, når de genoptager et så tvivlsomt programkoncept.

11. Dette spørgsmål skal tages med det absolutte forbehold, at man ikke kan betragte ansøgere med etnisk minoritetsbaggrund som en homogen gruppe. Hvad der kan gøre prøven vanskeligere vil være individuelt. Alligevel har jeg forsøgt at indkredse, om der er generelle problemer.

12.Spørgsmål 4, 1998.

13.Prøven i 1996

14. At logikken i praksis ikke holder ses blandt andet på antallet af kvalificerede personer med etnisk minoritetsbaggrund inden for feltet, som slet ikke får chancen for komme ind ved medierne.

\section{Litteratur}

Barth, Fredrik (1994): Analysen av kultur i komplekse samfunn, i Manifestasjon og prosess. Oslo Universitetsforlag.

Bauman, Zygmunt (1973/1999): Culture as Praxis. Sage London, California, New Delhi.

Berger, Peter \& Luckmann, Thomas (1966): Den samfundsskabte virkelighed. Lindhardt \& Ringhof.
Bourdieu, Pierre (1980/1990): The Logic of Practice. Cambridge: Polity Pres; Stanford University Press.

Bourdieu, Pierre (1978): Outline of a theory of Practice. Cambridge: Cambridge University Press.

Bourdieu, Pierre (1998): Om TV - og journalistikkens magt. København: Tiderne Skifter.

Bourdieu, Pierre (1997): Men hvem skabte skaberne? - interviews og forelæsninger. Akademiske Håndbøger.

Bourdieu, Pierre \& Wacquant, Loïc (1996): Refleksiv sociologi - mål og midler. København: Hans Reitzels forlag.

Christiansen, Connie Carøe \& Lea Sell (2000): Godt stof eller medborger? - Nyheder og etniske minoriteter i Danmark. Socialforskningsinstituttet.

Danmarks Radio (1999): Danskernes DR: DRs ønsker og forslag til ny mediepolitisk aftale. København: Danmarks Radio.

Dansk Journalistforbunds arbejdsgruppe for etnisk ligestilling i medierne: Forslag til Hovedbestyrelsesmøde, december 1999, og delegeretmøde i år 2000.

Fairclough, Norman (1995): Media Discourse. Arnold, A member of the hodder Headline Group.

Frachon, Claire \& Vargaftig (ed.) (1995): European Television - Immigrants and Ethnic Minorities, Council of Europe, John Libbey.

Hall, Stuart (1992): Modernity and its Futures. London:Polity Press, Open University.

Harbo, Per, Fruensgaard, Karen og Thormann Karen (1999): Tosprogede elevers socialisering. Mulernes Legatskole Odense,

Held, David (1987): Models of Democracy, Cambridge: Polity Press.

Hervik, Peter red. (1999): Den generende forskellighed - Danske svar på den stigende multikulturalisme. København: Hans Reitzels forlag.

Hjarvard, Stig (1999): TV-nyheder i konkurrence. København: Samfundslitteratur.

Husband, Charles (ed.) (1994): A Richer Vision: The Development of Ethnic Minority Media in Western Democracies. Paris: UNESCO Publishing.

Hussain, Mustafa, Ferruh Yilmaz \& Tim O’Connor (1997): Medierne, minoriteterne og majoriteten - en undersøgelse af nyhedsmedier og den folkelige diskurs i Danmark. København: Nævnet for Etnisk Ligestilling.

Jensen, Iben (1991): Film, Kultur, Betydning - En tværkulturel receptionsanalyse af »Yol«. Reproserien 4/91. København: Københavns Universitet, Institut for Kultursociologi.

Jensen, Iben (1998): Interkulturel kommunikation i komplekse samfund. København: Roskilde Universitetsforlag.

Jensen, Iben (2000a): Kulturforståelse. København: Center for Tværkulturelt Boligarbejde.

Jensen, Iben (2000b): Hvornår er man lige kvalificeret? Etniske minoriteters professionelle adgang til etablerede danske medier. København: Nævnet for Etnisk Ligestilling.

Liebes, Tamar \& Elihu Katz (1993): The Export of Meaning. Cross-cultural Readings of Dallas. Oxford: Polity Press. 
Lund, Anker Brink (1997): Smitsomme sygdomme i dansk journalistik. Købehavn: Munksgaard.

Løngreen, Hanne (1991): »Visuel kommunikation i et interkulturel perspektiv«, Tendens - Tidsskrift for kultursociologi 3.3 årg. nr. 3

Løngreen, Hanne (1992): »Billeder på tvärs af kulturer« i Lundström og Sahlström (red.) Talepråk, Skriftspråk, Bildspråk, SIC 35, University of Linköbing.

Melis, Isabel (2000): Examples of »good practices« to fight against racism and intolerance in the European media. (Web-site: www.ecri.coe.int)

Mørck, Yvonne (1998): Bindestregsdanskere. København: Dansk Sociologi.

Philips, Louise \& Marianne Winther Jørgensen (1999): Diskursanalyse - som teori og metode. København: Roskilde Universitetsforlag.

Pilger, John (1998) Den skjulte dagsorden. København: Fremad.

Poulsen, Jørgen (1999): Kultur og betydning - kommunikation som kulturel og social praksis, København: Samfundslitteratur.

Quraishy, Bashy (2000): »Mediernes rolle i integrations arbejde« (17.6.2000)

Singh, Europe \& Jeffrey Morris (1995): Recommenda- tions for Broadcasting on Fair Portrayal of Ethnic Minorities in European Societies. London: Public Broadcasting for a Multicultural Europe.

Stjer, Christian (2000): IntegrationsStatus. Grafikrapport: Dansk Flygtningehjælp. 1. kvartal 2000 - Tv-medier. Catinét, Aps.

Thorup, Mette-Line (2000): »Indvandrere fylder specialklasserne«, Information (3.5.200)

Ugeposten d. 4. juli 2000: »Naboer frygter for deres døtre

van Dijk, Teun A. (1988): News as discourse. LEA. Lawrence Erlbaum Associates, Publishers, Hillsdale, New Yersey.

van Dijk, Teun. A. (1991): Racism and the press. London: Routledge.

Yilmaz, Ferruh (1999): »Konstruktion af de etniske minoriteter: Eliten, medierne og »etnificeringen« af den danske debat« i Politica 31. årg. nr. 2. 1999.

Iben Jensen er adjunkt på Institut for kommunikation, journalistik og datalogi på RUC. 